\title{
Trabalhadores, greves, campanhas e repressão em Alagoas (1961 - 1964)
}

\section{Rodrigo José da Costa*}

Resumo: Pretendemos, neste artigo, fazer uma exposição da pesquisa realizada sobre as lutas sociais em Alagoas no período anterior ao golpe civil-militar de 1964. A partir do uso das fichas pessoais da Delegacia de Ordem Pessoal, Social e Econômica - DOPSE e da pesquisa feita no jornal A Voz do Povo, editado pelo PCB em Alagoas, e dos jornais da grande imprensa alagoana do período, buscamos fazer uma análise das greves e das campanhas políticas e sociais, bem como da repressão sofrida pelos trabalhadores e pelos grupos de esquerda em geral no período, chamando a atenção para as peculiaridades do caso alagoano. A atuação cada vez mais intensa dos grupos de esquerda em Alagoas no início da década de 1960 foi alvo de uma forte repressão policial comandada pelo governador do estado, o major Luiz Cavalcante. A partir dos eventos narrados nos jornais pesquisados, procuramos mostrar a mobilização dos grupos de esquerda no referido período, bem como as medidas repressivas do governador para conter a atividade desses grupos.

Palavras-chave: Golpe civil-militar - História de Alagoas - Trabalhadores - Greves

Abstract: This article aims to presente the research conducted on social struggles in Alagoas in the period before the civil-military coup of 1964. From the use of the personal files of the Police Order Personal, Social and Economic - DOPSE and the research done in A Voz do Povo newspaper published by the Communist Party at Alagoas, and the mainstream press, we seek to analyze the strikes and political campaigns and social carried out as well as the repression suffered by workers and leftists in general in the period, drawing attention to the peculiarities of the case of state of Alagoas. The performance of increasingly intense leftist groups in Alagoas in the early 6os was the target of a strong police repression led by the state governor, major Luiz Cavalcante. From the events recounted in the newspapers surveyed, try to show the mobilization of leftist groups in that period as well as the repressive measures of the governor to stop the activity of these groups.

Keywords: Civil-military coup - History of Alagoas - Workers - Strikes

Uma das consequências do golpe civil-militar de março de 1964 foi o estancamento da democracia, que se expressava pela demanda da ampliação da cidadania dos trabalhadores urbanos e rurais. No triênio 1961/1963, o sindicalismo brasileiro

* Mestre em História pela Universidade Federal de Pernambuco. Este artigo traz fragmentos dos capítulos 2 e 3 da seguinte dissertação: COSTA, Rodrigo José da. O golpe civil-militar em Alagoas: o governo Luiz Cavalcante e as lutas sociais (1961-1964). Dissertação (Mestrado em História). PPGH-UFPE, Recife, 2013. 
alcançou um de seus momentos de mais intensa atividade. Enquanto nos anos de 1958 a 1960, sob o governo Juscelino Kubitschek, ocorreram cerca de cento e oitenta greves, nos três primeiros anos de João Goulart foram deflagradas mais de quatrocentas e trinta paralisações. ${ }^{1}$

Lucilia Delgado aponta que a crise institucional que caracterizou os primeiros anos da década de 1960 foi antecedida por um período de euforia e de crença no futuro. Segundo a autora, os anos de 1950, especialmente a segunda metade desta década, ecoaram para a posteridade como um período de esperança e de fé na modernidade. No entanto, a essa lembrança de um passado coletivo que vislumbrava o futuro com olhar de otimismo, acopla-se outra lembrança coletiva, relativa à conjuntura histórica imediatamente subsequente ao contexto dos anos de 1950. Nesse caso, para Delgado, "o que vem à tona são lembranças, não de um tempo marcado pela convicção no progresso, mas sim outro tempo caracterizado por conflitos sociais e políticos". ${ }^{2}$

Conflitos esses protagonizados por segmentos sociais, por organizações da sociedade civil e por partidos políticos que projetavam perspectivas opostas sobre o futuro do país. Se os anos cinquenta foram os anos da euforia, o início dos anos sessenta foi um período de conflito aberto nas sociedades civil e política, bem como de crise institucional.

Nesse período, diferentes organizações de coordenação dos sindicatos, no plano regional e nacional, foram criadas. Embora proibido pela rígida legislação sindical vigente, o Comando Geral dos Trabalhadores (CGT) teve uma destacada atuação na cena política brasileira. Juntamente com outras centrais sindicais de menor vulto, o CGT foi responsável pelas primeiras greves explicitamente de caráter político na história brasileira.

Caio Toledo afirma que, "para afronta dos setores de direita, as lideranças do CGT eram recebidas em Palácio pelo presidente da República e reconhecidas como interlocutoras de importantes dirigentes partidários". 3 A imprensa conservadora designava o CGT como o "quarto poder", reforçando o fantasma, forjado na época de Vargas, de que Goulart visava instituir no país uma "República sindicalista". ${ }^{4}$

Durante todo o período, foi muito estreita a vinculação do CGT com o governo Goulart. Embora não se possa afirmar que tenha sido apenas "massa de manobra" do governo - pois reivindicava sua autonomia - , o CGT colaborou estreitamente com Goulart, apoiando-o abertamente na maioria de suas iniciativas políticas. Tal compromisso era justificado pelo fato de a ideologia nacional-desenvolvimentista, elaborada pelo Partido Comunista Brasileiro (PCB) e hegemônica dentro do CGT, ser convergente com as propostas reformistas de Goulart.

A luta pela cidadania política dos trabalhadores do campo também se constituiu numa realidade nova na história social do país. As Ligas Camponesas, que notabilizaram o advogado e deputado federal Francisco Julião, nasceram das lutas de resistência de pequenos agricultores não proprietários contra a tentativa de expulsão das terras onde trabalhavam; de 1959 a 1962, as Ligas tiveram uma

1 TOLEDO, Caio Navarro de. 1964: O golpe contra as reformas e a democracia. Revista Brasileira de História. 2004, v.24, n.47, p. 13-28.

2 DELGADO, Lucilia de Almeida Neves. Trabalhadores na crise do populismo: utopia e reformismo. In: TOLEDO (Org.). 1964: visões críticas do golpe. Campinas: Editora da UNICAMP, 1997. p. 55.

3 TOLEDO, C. N. de. O golpe contra as reformas e a democracia. In: REIS, Daniel Aarão; RIDENTI, Marcelo; MOTTA, Rodrigo Patto Sá (Orgs.). O golpe e a ditadura militar: 40 anos depois (1964-2004). Bauru: EDUSC, 2004, p 71.

4 Ibidem. 
acelerada expansão em todo o Nordeste. Elas contestavam a dominação política e econômica à qual as populações rurais estavam secularmente submetidas. Em algumas localidades, ocorreram conflitos armados entre camponeses e proprietários de terras; lideranças camponesas eram perseguidas a mando dos latifundiários, alarmados com a politização das massas rurais. ${ }^{5}$

Extensas reportagens, em revistas e jornais do Brasil e do exterior, informavam seus leitores acerca da ação e dos objetivos, subversivos e revolucionários, das Ligas Camponesas. O Nordeste, faminto e sedento, estaria a um passo de uma radical e violenta "guerra camponesa"; era a conclusão a que se chegava com essas alarmistas reportagens da grande imprensa. ${ }^{6}$

Outras reivindicações políticas visavam ao alargamento da democracia liberal vigente no país: entre elas, o direito de voto aos analfabetos, o direito dos setores subalternos das Forças Armadas de postularem cargos eletivos (a carta de 1946 lhes vedava esse direito) e a legalidade do PCB, posto fora da lei desde 1947. Embora alguns de seus membros conseguissem ser eleitos por outros partidos, tivessem lideranças em sindicatos, editassem revistas e semanários, o PCB não podia realizar seus encontros e reuniões senão de forma clandestina e estava sob permanente repressão policial. A inexistência do pluralismo ideológico se constituía no pré-64 numa séria deformação da democracia política existente no país.

E é justamente no início da década de 1960, que, de acordo com Marco Aurélio Santana7, observar-se-á os comunistas trabalhando intensamente no movimento sindical, talvez como nunca o fizeram antes. Eles ocuparam a direção, em parceria ou isolados, das principais instituições sindicais do país e, mais uma vez, ainda que na ilegalidade, influenciaram a vida política nacional, participando ativamente dos movimentos que sacudiram a política naquela conjuntura. A turbulência foi de tal ordem que a ameaça do que se chamou "República Sindicalista" ${ }^{\text {foi utilizada }}$ para justificar a precipitação do golpe civil-militar de 1964.

Os trabalhadores alagoanos viveram um período de intensa atividade no início da década de 1960, depois de vivenciarem conquistas importantes no tocante a direitos trabalhistas na década anterior. Organizados em sindicatos, estando formalmente ligados ao PCB ou não, se tornaram um obstáculo para o governador Luiz Cavalcante (União Democrática Nacional - UDN), assim como que para com o bloco político que este último representava.

Em consonância com a mobilização dos trabalhadores do resto do país, os trabalhadores alagoanos exerciam um protagonismo cada vez maior nos destinos políticos e sociais daquele período. ${ }^{9}$ Os operários têxteis ${ }^{10}$ das fábricas de fiação e

5 Sobre o assunto, ver: MONTENEGRO, Antônio Torres. Ligas Camponesas e sindicatos rurais em tempo de revolução. In: FERREIRA, Jorge; DELGADO, Lucilia de Almeida Neves (Orgs.). O tempo da experiência democrática: da democratização de 1945 ao golpe civil-militar de 1964. Rio de Janeiro: Civilização Brasileira, 2008. (O Brasil Republicano; v. 3).

6 Cf.: TOLEDO. O golpe contra as reformas e a democracia. In: REIS, Daniel Aarão; RIDENTI, Marcelo; MOTTA, Rodrigo Patto Sá (Orgs.). O golpe e a ditadura militar: 40 anos depois (1964-2004). op. cit., p. 72.

7 SANTANA, Marco Aurélio. Homens partidos: comunistas e sindicatos no Brasil. São Paulo: Boitempo, 2001, p. 81.

8 Naquela conjuntura, a sucessão de greves e o fortalecimento do sindicalismo foram usados como mote para que os grupos de direita precipitassem o golpe de estado. Sob a alegação da necessidade de fazer frente à "ofensiva" do movimento sindical, os setores conservadores levaram à frente a conspiração que acabou por deflagrar o movimento militar em abril de 1964.

9 Sobre esse protagonismo, ver: REIS, Daniel Aarão. O colapso do colapso do populismo ou a propósito de uma herança maldita. In: FERREIRA, Jorge (Org.). O populismo e sua história: debate e crítica. Rio de Janeiro: Civilização Brasileira, 2001. p. 319-379.

10 LESSA, Golbery. Trama da Memória, Urdidura do Tempo: Ethos e lugar dos operários têxteis alagoanos. Maceió, manuscrito, 2008. 
tecelagem de Maceió, além de outros segmentos, como os portuários, os rodoviários, os bancários e os trabalhadores na extração de petróleo, tiveram importante papel na defesa das Reformas de Base e em outras campanhas, como a defesa da Legalidade em agosto de 1961 e o plebiscito pelo presidencialismo em 1963.

Nas linhas que seguem, relacionamos algumas das greves que aconteceram entre 1961 e 1964, além de algumas campanhas políticas desenvolvidas pelos trabalhadores alagoanos neste período. É importante salientar que encontramos muitas notícias sobre a deflagração de greves, que aconteceram quase na sua totalidade na capital Maceió, mas que na sua grande maioria não ocuparam mais que uma pequena nota nos jornais pesquisados.

Dessa forma, optamos pela análise dos movimentos que tiveram uma relativa cobertura dos fatos e que puderam fornecer elementos para uma visão ampliada - e passível de crítica - do seu desenrolar e das suas consequências. Ainda assim, esbarramos em alguns obstáculos ao longo do caminho. Nos três jornais pesquisados (Gazeta de Alagoas, Jornal de Alagoas e A Voz do Povo), por vezes nos deparamos com a alternância entre a cobertura de um acontecimento em um jornal e o silêncio do outro em relação ao mesmo fato.

O jornal Gazeta de Alagoas, de propriedade do ex-governador de Alagoas, Arnon de Mello, a partir de meados de 1962, começou a atacar o governador Luiz Cavalcante, tecendo críticas a sua administração, incorporando um discurso de defesa das classes trabalhadoras em suas reivindicações e lutas. Nesse âmbito, acaba por se desenrolar um embate em que a Gazeta assume uma posição de oposição ao governo estadual, ao passo que o Jornal de Alagoas, periódico ligado aos Diários Associados ${ }^{11}$, de Assis Chateaubriand, dedica-se a defender o governo de Luiz Cavalcante.

O jornal A Voz do Povo foi o órgão oficial de imprensa do Comitê Estadual do PCB em Alagoas. Sua existência de aproximadamente dezoito anos foi marcada por diversas interrupções, devido a proibições, fechamentos, empastelamentos e apreensões. Foi considerado um dos principais instrumentos de ação desse partido no estado, tendo integrado uma rede (ou cadeia) de jornais populares que o Comitê Central do PCB havia decidido criar, entre 1945-1946, em todas as capitais do país. Entre 1951 e 1964, foi fechado e empastelado diversas vezes. Nesse período, teve como diretores Jayme e Nilson Miranda. Sua última edição foi publicada em $1 .^{\circ}$ de abril de 1964, quando ocorreu o empastelamento do jornal e a queima dos seus exemplares por forças policiais e/ou paramilitares. ${ }^{12}$

\section{Legalização e legalidade}

Em 1961, o PCB empreendeu uma campanha visando obter a legalização da sua legenda eleitoral ${ }^{13}$, perdida durante o governo do Presidente Eurico Dutra, em

11 Os Diários Associados foram uma das maiores empresas jornalísticas da história da imprensa no Brasil. Seu proprietário, Assis Chateaubriand, foi um dos homens públicos mais influentes do país nas décadas de 1940 e 1960, destacando-se como jornalista, empresário e político. No seu auge, os Diários Associados reuniam, em todo o Brasil, trinta e seis jornais, dezoito revistas, trinta e seis rádios e dezoito emissoras de televisão, além de bater recordes de tiragem com a revista $O$ Cruzeiro.

12 Para mais informações sobre este jornal, ver: MACIEL, Osvaldo Batista Acioly. A Voz do Povo: Um Registro da Esquerda Alagoana (1954-1964). Cabanos - Revista de História, v. 1, 2008, p. 129-144.

13 "Representantes de Várias Correntes Políticas Manifestaram-se Favoráveis à Legalidade do Partido Comunista Brasileiro". In: A Voz do Povo. Maceió, Ano XV. 27 ago. 2008, n.32, p. 01. Na edição de 24 de setembro, há uma matéria sobre a campanha de coleta de assinaturas que iria se realizar. "Comunistas Iniciam a Campanha de Coleta de assinaturas pelo registro eleitoral do partido comunista brasileiro". In: A Voz do Povo. Maceió, Ano XV. 24 set. 1961, n. 36, p.1. 
1947. Após um comício realizado em 6 de agosto do mesmo ano, acabaram detidos Áureo Calazans de Albuquerque ${ }^{14}$, operário na Fábrica Têxtil de Rio Largo, Solon Araujo ${ }^{15}$, funcionário da Câmara de Vereadores de Maceió, e o mecânico Júlio de Almeida Braga ${ }^{16}$ e seu filho Laudo Leite Braga ${ }^{17}$, que era militar do $20 .{ }^{0}$ Batalhão de Caçadores de Maceió, exercendo a função de redator do jornal $A$ Voz do Povo.

Poucos dias depois, a crise que teve início no país com a renúncia do Presidente Jânio Quadros e com a "Campanha da Legalidade", que se iniciou para garantir a posse do vice João Goulart, mais uma vez colocou a repressão policial contra os que se manifestaram a favor da posse de Jango e contra o golpe urdido pelos ministros militares. ${ }^{18} \mathrm{~A}$ repercussão desse evento movimentou os ânimos dos diversos grupos sociais alagoanos.

No dia da posse de Goulart, 7 de setembro de 1961, foi organizado um comício no qual os manifestantes comemoraram a vitória do movimento da Legalidade. ${ }^{19}$ Parlamentares, líderes estudantis, sindicais e jornalistas que lutaram pela garantia da Legalidade enfrentaram a oposição de Luiz Cavalcante, que tomou posição ao lado dos que tentaram barrar a posse de Jango. ${ }^{20}$

Dias antes, no dia 28 de agosto, as entidades estudantis convocaram concentração cívica na escadaria da Assembleia Legislativa Estadual e enfrentaram a polícia política para repudiar o golpe militar. No dia seguinte, os estudantes programaram uma passeata que foi impedida pelo $20 .^{\circ} \mathrm{BC} . .^{21}$

No entanto, a bancada de senadores de Alagoas, incluindo Silvestre Péricles, Rui Palmeira e Afrânio Lages, posicionou-se contra a Legalidade e votou a favor da emenda que instituía o parlamentarismo e, com isso, foi alvo de críticas por parte do jornal A Voz do Povo. ${ }^{22}$ Posteriormente, a Assembleia Legislativa aprovaria as posições assumidas por Leonel Brizola, governador do Rio Grande do Sul, e pelo General Machado Lopes, Comandante do III Exército na defesa dos princípios constitucionais. ${ }^{23}$

Mas essa vitória momentânea foi apenas um dos inúmeros capítulos que se desenrolariam a partir de então. Durante um comício da União de Estudantes do Estado de Alagoas (UEEA), no início de 1962, um dos principais articuladores do PCB em Alagoas, Nilson Miranda, é preso juntamente com outros jornalistas. Por

14 Delegacia de Ordem Política Social e Econômica. Pasta 01, Ficha Pessoal 12. Em Alagoas, a polícia política se estruturou no final da década de 1930, quando foi criada a Delegacia de Ordem Política e Social - DOPS. A referida delegacia se vinculou à Secretaria dos Negócios do Interior, Educação e Saúde. Em 17 de julho de 1946, o Diário Oficial traz a primeira mudança. Com o decreto-lei n. ${ }^{\circ} 3.189$, de 16 de julho de 1946, a delegacia passa a se denominar Delegacia de Ordem Política e Social, Investigações e Capturas - DOPSIC. Entre 1946 e 1964, a Secretaria dos Negócios do Interior, Educação e Saúde foi sendo desmembrada. Entre outras, surge a Secretaria dos Negócios do Interior, Justiça e Segurança Pública. Por fim, em 07 de fevereiro de 1964, por meio da Lei n. ${ }^{\circ} 2.658$, publicada no Diário Oficial de 09 de fevereiro de 1964, o DOPSIC foi desmembrado em duas delegacias: Delegacia de Roubos, Furtos, Investigações e Capturas (DRFIC) e a Delegacia de Ordem Política, Social e Econômica (DOPSE).

15 DOPSE. Pasta 04, Ficha Pessoal 80.

16 DOPSE. Pasta 07, Ficha 133.

17 DOPSE. Pasta 07, Ficha 134.

18 Sobre o evento e seus desdobramentos, ver: TOLEDO, Caio Navarro. O Governo Goulart e o Golpe de 64. São Paulo: Brasiliense, 1982; REIS FILHO, Daniel Aarão. Ditadura Militar, Esquerdas e Sociedade. Rio de Janeiro: Jorge Zahar, 2000; FERREIRA, Jorge. O governo Goulart e o golpe civil-militar de 1964. In: FERREIRA, Jorge. (org.). O Brasil Republicano, op. cit.

19 "Povo no Grande Comício do Parque Rodolfo Lins Comemorou Vitória Sobre o Golpismo". In: A Voz do Povo. Maceió, Ano XV. 10 set. 1961, n. 34, p.1.

20 Ibidem.

21 "Câmara de Vereadores Foi Trincheira de Luta em Defesa da Democracia". In: A Voz do Povo. op. cit., p. 4.

22 "O Povo Saberá Julgar Aqueles que Traíram a sua Confiança". In: A Voz do Povo. Ibidem.

23 “Leonel Brizola e Machado Lopes Cidadãos Honorários de Alagoas". In: A Voz do Povo. Maceió, Ano XV. 17 set. 1981, n.35, p.1. 
meio da matéria publicada no dia 21 de janeiro no jornal $A$ Voz do Povo, sobre a prisão de Miranda, se soube que a versão de que os policiais prenderam o jornalista por ele estar portando um revólver era uma "farsa". A denúncia feita pelo jornal é que a referida arma teria sido "plantada" no carro de Miranda. ${ }^{24}$

Dias depois, o Comitê do PCB lançaria um manifesto, contando com o apoio de diversos sindicatos, de repúdio ao "sequestro"25, mas que, em seguida, também sofreu repressão policial, pois terminaram sendo presos alguns dos manifestantes que assinaram a lista de solidariedade que protestava contra a prisão de Nilson Miranda. Nas fichas pessoais pesquisadas foram encontradas as prisões de Rubens Colaço ${ }^{26}$, presidente do Sindicato dos Rodoviários e destacado membro do PCB em Alagoas e de Daniel Augusto de Alcântara ${ }^{27}$, presidente do Sindicato dos Metalúrgicos.

No mês seguinte, a greve dos comerciários também foi repreendida violentamente, a ponto de os policiais, armados com fuzis e metralhadoras, exigirem que os comerciantes abrissem as portas de seus respectivos estabelecimentos. Os abusos praticados seriam repudiados nos meios sindicais e denunciados na Assembleia Legislativa. ${ }^{28}$

Uma greve em agosto de 1962 foi deflagrada pelas tecelãs, por conta do aumento do número de maquinário que cada trabalhadora deveria manusear, e durou três dias, paralisando o trabalho na Fábrica Carmen, situada no distrito operário de Fernão Velho, em Maceió. ${ }^{29} \mathrm{Na}$ edição do dia 25 de agosto, o Jornal de Alagoas trazia uma matéria, informando sobre a realização de uma reunião do Sindicato dos Trabalhadores da Indústria Têxtil de Fernão Velho que deliberaria sobre a greve..$^{30}$ Havia alguns dias que os proprietários daquela indústria haviam ordenado que os operários devessem manusear seis teares, sendo que já trabalhavam com quatro. A reunião visava apelar para a classe patronal, a fim de que essa mudança não fosse levada à frente, mas nenhum entendimento foi concretizado. O presidente do sindicato dos trabalhadores, Sr. José Conrado, convocou uma assembleia e foi deliberado que, se dentro de 48 horas não fosse restabelecido o trabalho com quatro teares, os operários decretariam greve.

Também no dia 25, a Gazeta de Alagoas, na matéria "Operários de Fernão Velho em Questão com a Fábrica"31, afirmava que o presidente do sindicato teria procurado a gerência da fábrica, a fim de apresentar o problema. A empresa fez a contraproposta de cinco teares por cada tecelã, o que não foi aceito pelo sindicato. No final da matéria, um dado interessante: "Inesperadamente, e para surpresa de todos, carros da Rádio Patrulha estiveram durante a segunda e terça-feira passadas em Fernão Velho, como que à espera de algo de anormal ou para coagirem as operárias".

24 "Polícia de Luiz Cavalcante Desencadeia Terror Contra Povo e Estudantes, Agride, Sequestra e Prende Jornalistas no Comício da UEEA". In: A Voz do Povo. Maceió Ano XVI. 21 jan. 1962, n. 01, p.1.

25 A referida matéria usa o termo "sequestro" ao se referir à abordagem da polícia.

26 DOPSE. Pasta 11, Ficha Pessoal 214. Sobre a trajetória de Colaço, ver: MAJELLA, Geraldo de. Rubens Colaço: Paixão e vida - A trajetória de um líder sindical. Maceió; Recife: Edições Bagaço, 2010.

27 DOPSE. Pasta 01, Ficha Pessoal 19.

28 "Governo Fascista Lança Mão do Terror Policial para Intimidar os Comerciantes". In: A Voz do Povo. Maceió, Ano XVI. 18 fev. 1962, n. 03, p. 1.

29 Sobre os acontecimentos dessa greve, ver: FARIAS, Ivo dos Santos. Dominação e resistência operária no núcleo fabril de Fernão Velho/AL (1953-1962). Dissertação (Mestrado em Sociologia). PPGS-UFAL, Maceió, 2012, além de: MELO, Airton de Souza. Operários têxteis: organização sindical, repressão e vida na fábrica (1951-1964). Dissertação (Mestrado em História). PPGH-UFPE, Recife, 2012.

30 Jornal de Alagoas. 25 ago. 1962, p. 04.

31 Gazeta de Alagoas. 25 ago. 1963, p. 06. 
Não conseguimos obter informações nos jornais pesquisados sobre o desfecho dessa greve, mas gostaríamos de chamar a atenção para dois aspectos em particular: 1) o fato de ser uma greve organizada e deflagrada de dentro da fábrica, demonstrando o nível de politização e a capacidade de mobilização dos seus trabaIhadores, uma vez que os acontecimentos se desdobraram em praticamente uma semana; 2) o nível de articulação por parte da classe patronal para com os setores dirigentes e, por conseguinte, com o aparato policial do estado, tendo em vista a rapidez com que acorreu a polícia para o distrito operário, muito provavelmente prevenida da possibilidade de ter que lidar com operários mobilizados em greve.

\section{A intensificação das lutas}

Posteriormente, o PCB começou a atuar em nova frente de mobilização: o processo de Sindicalização Rural ${ }^{32}$, processo esse que foi mais um elemento a acirrar a disputa entre a elite dominante e o PCB. Mario Grynszpan ${ }^{33}$, discutindo de forma ampla sobre a questão agrária no Brasil republicano, localiza os anos do início da década de 1960 como fase de aceleração, tanto dos processos de luta pela terra como também da percepção de intelectuais e políticos sobre a necessidade de equacionamento da questão agrária como pauta fundamental para os projetos nacionais de desenvolvimento. Segundo o autor, este período foi fundamental na produção e na consolidação de "novos esquemas e categorias de percepção da realidade brasileira, de seus problemas e também de suas soluções", que repercutiram decisivamente sobre as ações políticas dos agentes envolvidos com a questão. Na avaliação de Grynszpan, dada a sua profundidade, "os efeitos desses processos se impuseram mesmo durante os governos militares e se estendem até hoje, ainda que com redefinições importantes ao longo do tempo, mantendo presente a questão agrária". ${ }^{34}$

Fernando Medeiros aponta que dentro de sua perspectiva de "reforma agrária" o governo Luiz Cavalcante promoveu em 1961 o projeto de assentamento de famílias de trabalhadores rurais nos municípios de Maceió e Rio Largo ${ }^{35}$ e destinou, em 1963, uma área de 950 hectares, no tabuleiro do Pilar, para formar um núcleo de colonização que deveria receber do governo toda a infraestrutura e a assistênciatécnica necessárias. ${ }^{36}$

Medeiros destaca que:

Com seu discurso e práticas acerca da reforma agrária Luiz Cavalcante atacava em cheio o governo federal ao transmitir à opinião pública a ideia de que a realização da reforma agrária não seria um problema, nem seu governo se opunha à mesma. O problema estaria colocado na maneira como o governo Goulart pretendia realizá-la, de forma radical e fora da lei. ${ }^{37}$

32 O jornal A Voz do Povo publicou na íntegra o texto do decreto n. ${ }^{\circ} 7.038$, de 20/11/1962, que regulamentou o processo de sindicalização rural. "Assinado Decreto de Sindicalização Rural”. In: A Voz do Povo. Maceió, Ano XVI. 09 dez. 1962, n. 37, p. 03.

33 GRYNSZSPAN, Mario. O período Jango e a questão agrária: luta política e afirmação de novos atores. In: FERREIRA, Marieta de Moraes. João Goulart: entre a memória e a história. Rio de Janeiro: FGV, 2006.

34 Ibidem, p. 75 .

35 MEDEIROS, Fernando Antonio Mesquita. O homo inimicus: igreja, ação social católica e imaginário anticomunista em Alagoas. Maceió/AL: Edufal, 2007, p. 137.

36 Jornal de Alagoas. Maceió, 11 jan. 1963, p. 04.

37 MEDEIROS, op. cit., p. 137. 
Ainda de acordo com Medeiros, a preocupação de Luiz Cavalcante com a reforma agrária advinha, sobretudo, da necessidade de controle sobre o movimento social no campo:

Reconhecida a gravidade que assumia a questão agrária no país e a intensificação das lutas que dela decorriam, tornava-se necessário reduzir as tensões, realizando assentamentos em áreas pertencentes ao próprio governo estadual ou em pequenas áreas, como os realizados em União dos Palmares, Santana do Mundaú e Murici, que contavam com a aprovação dos empresários da agroindústria canavieira e eram feitos dentro das determinações do IPES/IBAD. Mantinha-se, desta forma, a mesma estrutura fundiária ao não tocar nos latifúndios de propriedade das usinas e dos fornecedores de cana. Seguindo o mesmo princípio de controle o governo incentivou a organização de sindicatos rurais que poderiam, caso fossem de alguma forma controlados, representar uma alternativa às Ligas Camponesas que ganhavam projeção em estados vizinhos como Pernambuco. ${ }^{38}$

No começo de 1963, os trabalhadores alagoanos ligados ao PCB e ao CGT, juntamente com o governador Luiz Cavalcante, mobilizavam-se na campanha pelo plebiscito que restaurou os poderes presidenciais de João Goulart. Em 1962, quando todos os ministros do gabinete de Tancredo pediram demissão, em seu lugar assumiu Francisco de Paula Brochado da Rocha, com um programa que priorizava o combate à inflação e a antecipação do plebiscito destinado a decidir sobre a continuidade ou não do regime parlamentarista, previsto para o início de 1965.39 Mas as demandas pela antecipação do plebiscito estavam postas e, sob pressão do movimento sindical, das esquerdas e de setores militares, o Congresso aprovou sua antecipação para 6 de janeiro de $1963 .{ }^{40}$

No dia 6 de janeiro, dia de votação, o Jornal de Alagoas publicou uma matéria na qual o CGT alagoano convocava "os eleitores a comparecer as urnas e dizer 'não' ao Regime". ${ }^{41}$ Por meio de um manifesto assinado pelo presidente do CGT no estado, Alan Rodrigues Brandão, entre outros quinze presidentes de sindicatos trabalhadores locais, "foi ontem lançado neste capital, conclamando as classes operárias, estudantis, camponesas, militares, servidores públicos e o povo em geral a votarem 'não' no referendo de amanhã”.

Na mesma edição, com matéria intitulada "Governador comanda o 'não' e pede aos prefeitos que o ajudem: plebiscito" 42 , o jornal informava que o governador Luiz Cavalcante havia telegrafado a todos os prefeitos do interior do estado, "encarecendo-lhes todo o empenho para que seja significativo o comparecimento do eleitorado ao plebiscito de hoje”. Na continuação da matéria, o jornal afirma que

38 MEDEIROS, Idem. O Instituto Brasileiro de Ação Democrática (IBAD) foi uma organização anticomunista fundada em 1959. Ao lado dele, vários empresários fariam parte dessa organização e da sua "entidadeirmã", o IPES. O Instituto de Pesquisas e Estudos Sociais, fundado em 1961, serviu como um dos principais catalisadores da mobilização feita contra o governo João Goulart. Sua função primordial era integrar os diversos movimentos sociais de direita para criar as bases de uma oposição que pudesse deter o avanço do comunismo soviético no Ocidente. Sobre a atuação dessas duas organizações em Alagoas, ver: MELLO, Paulo Décio de Arruda. Alagoas: Sindicatos Rurais e Dominação. Dissertação (Mestrado em Desenvolvimento Agrícola). UFRRJ, Itaguaí, 1990.

39 GOMES, Angela de Castro; FERREIRA, Jorge. Jango: as múltiplas faces. Rio de Janeiro: FGV, 2007, p. 141.

40 Para uma discussão mais aprofundada sobre o plebiscito e seus desdobramentos, ver: MELO, Demian Bezzera de. O plebiscito de 1963: inflexão de forças na crise orgânica dos anos sessenta. Dissertação (Mestrado em História), PPGH-UFF, Niterói, 2009.

41 "CGT conclama eleitores a comparecer as urnas e dizer "não" ao Regime”. In: Jornal de Alagoas. 06 jan. 1963 , p. 6.

42 Jornal de Alagoas. 06 jan. 1963, p. 6. 
interrogado na campanha do 'NÃO', que vem comandando em Alagoas, o chefe do executivo já recebeu numerosas manifestações de prefeitos alagoanos, reafirmando-lhes solidariedade e prometendo que trabalharão para que seja [ilegível] e considerável o ‘NÃO' de Alagoas.43

Diante da divergência entre seus projetos políticos e expectativas quanto ao resultado do plebiscito, tanto o CGT quanto Luiz Cavalcante - e o grupo político que representava - defendiam a volta ao presidencialismo. Os grupos nacionalistas ligados ao PCB e ao CGT se alinhavam à política de união nacional defendida pelo PCB, que enxergava a possibilidade de concretização das Reformas de Base com a retomada dos poderes presidenciais de Goulart. Por seu turno, Luiz Cavalcante, como uma grande parcela da UDN no resto do país, apostava na necessidade de se restaurar o presidencialismo, para que nas eleições de 1965 tentassem repetir o êxito eleitoral de Jânio Quadros em 1960.

O plebiscito resultou, de fato, numa vitória consagradora para Jango. Cerca de nove milhões de eleitores, em dez milhões, ratificaram o mandato de Goulart, dizendo sim ao presidencialismo e ao programa de Reformas de Base, que se vinculara à sua restauração. ${ }^{44}$ Segundo Moniz Bandeira, Jango considerou aquele resultado "como outra eleição, sua verdadeira eleição para a presidência da República, a mais expressiva de toda a história do país", maior que a de Quadros, até então recorde, com seis milhões de votos.

Era seu "triunfo pessoal”, como o The New York Times reconheceu. Entretanto, não quis assumi-lo, em toda a plenitude, como um mandato popular para as Reformas de Base, e formar um ministério eminentemente de esquerda, a fim de executá-las, com ou contra o Congresso. "Essa coroa eu não ponho na minha cabeça" — disse Darcy Ribeiro, seu ministro da Educação. Seu propósito era deixar que a onda passasse, evitando a radicalização, para depois retomar, firmemente, o caminho das reformas. ${ }^{45}$

Jorge Ferreira aponta que a vitória de Goulart foi avassaladora: dos onze miIhões e quinhentos mil eleitores, nove milhões e quinhentos mil, ou seja, cinco em cada seis, votaram pelo regime presidencialista. Seu prestígio, naquele momento, era imenso. ${ }^{46}$

Findo o plebiscito, as lutas políticas em Alagoas aumentaram ao longo do ano de 1963. As disputas empreendidas na criação dos sindicatos rurais no interior do estado foi um dos palcos do embate entre Luiz Cavalcante e o PCB. No entanto, essa disputa não se deu exclusivamente entre o PCB e o governo do estado, envolvendo outros grupos, como a Igreja Católica por exemplo.

Em abril de 1963, o jornal A Voz do Povo denunciou em uma matéria que Fernando Oiticica, prefeito de Rio Largo, cidade componente do cinturão operário e

43 No trecho final da matéria, o Jornal de Alagoas afirma que um dia antes da votação, no Palácio dos Martírios, o governador LC havia reafirmado a um repórter a sua posição: "digamos não a esse regime que aí está que não é parlamentarismo nem nada, mas apenas, o regime de irresponsabilidade”.

44 BANDEIRA, Moniz. O governo João Goulart: as lutas sociais no Brasil, 1961-1964. 8. ed. São Paulo: Editora UNESP, 2010, p. 205.

45 Ibidem, p. 205-6.

46 FERREIRA e GOMES. Jango: as múltiplas faces. op. cit., p. 142. Em 2011, o historiador Jorge Ferreira publicou a biografia de João Goulart, na qual procura mostrar o ex-presidente sob o ponto de vista da ambiguidade. Mais do que ser uma simples biografia, Jorge Ferreira visita importantes aspectos da realidade contemporânea brasileira, principalmente naquele que ficou conhecido como o tempo da experiência democrática, compreendido entre 1946 e 1964. Para mais informações, ver: FERREIRA, Jorge. João Goulart: Uma biografia. Rio de Janeiro: Civilização Brasileira, 2011. 
industrial de Maceió, estaria impondo dificuldades para a criação do sindicato rural daquela cidade. ${ }^{47}$ Meses depois, o jornal do PCB traz numa matéria a denúncia que o presidente do Sindicato Rural de Santana do Mundaú, José Pedro de Lima, teria sido espancado por capangas a mando do proprietário do engenho onde morava e trabalhava..$^{48}$

O proprietário era o Deputado Estadual Antônio Gomes de Barros, ligado aos grupos dominantes da cidade de União dos Palmares. Lima teria sido agredido após uma reunião do Serviço de Orientação Rural (SORAL), ligado à Igreja Católica, que temia que o avanço do comunismo entre as comunidades rurais pudesse fazer com que uma onda de mobilizações no campo em Alagoas se transformasse em eventos como o das Ligas Camponesas em Pernambuco.

Enquanto as disputas no campo se acirravam, à medida que o debate pela Reforma Agrária do governo Jango ${ }^{49}$ se tornava mais denso, a atividade dos sindicatos urbanos também crescia. No mês de maio de 1963, alguns membros do PCB foram presos depois de comício organizado no Parque Rodolfo Lins.

O comício organizado pelo CGT contou com a participação dos demais membros do PCB, bem como dos sindicatos urbanos de maior representatividade em Maceió, dos operários têxteis e dos rodoviários. Terminaram presos o já mencionado presidente dos rodoviários Rubens Colaço, o estudante Agerson Dantas ${ }^{50}$, um membro do sindicato dos bancários, Anivaldo Miranda Aires ${ }^{51}$, o presidente do Sindicato Têxtil de Fernão Velho José Conrado Alves ${ }^{52}$, o presidente do Sindicato dos Portuários Luiz Gonzaga Alves ${ }^{53}$ e o advogado Rubem Ângelo ${ }^{54}$, figura de importante destaque por sua função do advogado do trabalho no sindicato têxtil de Fernão Velho.

Fernando Teixeira da Silva e Antonio Luigi Negro apontam que "o CGT nasceu de um esforço de militantes e operários no sentido de dar continuidade a iniciativas de criação de centrais sindicais, oficialmente proibidas, capazes de aglutinar amplas parcelas de trabalhadores em âmbito nacional". Seu objetivo não era apenas ampliar o leque de conquistas econômicas da classe operária, mas também interferir diretamente nas decisões políticas do país, articulando a luta dos sindicatos com instituições comprometidas com um plano de reformas estruturais para o Brasil. ${ }^{55}$

Segundo Lucilia Delgado ${ }^{56}$, o CGT surge como fruto de uma conjuntura de grande instabilidade política e social, caracterizada por amplas mobilizações populares e por propostas de modificações profundas na estrutura política e econômica do país. Decorreu também do processo anterior de luta sindical desenvolvido pelos trabalhadores das mais diversas categorias profissionais desde a década de 1940. Para a autora:

47 “Fernando Oititica Expulsa Camponês e Nega-se a Assinar o Edital de Convocação do Sindicato Rural”. In: Voz do Povo. Maceió, Ano XVII. 21 abr. 1963, n. 14, p. 4.

48 “Protestos de Massas Contra o Espancamento do Líder Camponês José Pedro de Lima”. In: A Voz do Povo. Maceió, Ano XVII. 04 ago. 1963, n. 26, p.2.

49 Cf.: FERREIRA. op. cit.; Cf.: REIS. op. cit.; Cf.: TOLEDO. op. cit.

50 DOSPE. Pasta 13, Ficha Pessoal 247.

51 DOPSE. Pasta 01, Ficha Pessoal 09.

52 DOSPE. Pasta 02, Ficha Pessoal 34.

53 DOPSE. Pasta 02, Ficha Pessoal 35.

54 DOPSE. Pasta 03, Ficha Pessoal 54.

55 Cf.: NEGRO, Antonio Luigi; SILVA, Fernando Teixeira. Trabalhadores, sindicato e política. In: FERREIRA, Jorge. op. cit., p. 72.

56 DELGADO, Lucilia de Almeida Neves. O Comando Geral dos Trabalhadores no Brasil 1961-1964. Petrópolis: Vozes, 1986. 
O fato é que o crescimento do movimento sindical se realiza mais a partir de uma grande "politização" de suas vanguardas do que de um trabalho de fortalecimento das entidades, através da ampliação de suas bases, a nível das empresas ou locais de trabalho. ${ }^{57}$

Entre os meses de junho e agosto de 1963, os trabalhadores do Porto de Maceió protagonizaram uma das mobilizações mais significativas do período. Em 7 de junho, os portuários alagoanos deflagraram uma greve em face da negativa do governador em atender suas reivindicações de aumento de salário, entre outros benefícios. ${ }^{58}$ No caso desta greve, será interessante perceber que o jornal Gazeta de Alagoas, de propriedade do ex-governador de Alagoas, e aquela altura senador, Arnon de Mello, aproveita-se de fatos como esses para atacar o governador Luiz Cavalcante, tecendo críticas a sua administração, incorporando um discurso de defesa das classes trabalhadoras em suas reivindicações e lutas. Nesse âmbito, acaba por se desenrolar um embate em que a Gazeta assume uma posição de oposição ao governo estadual, ao passo que o Jornal de Alagoas, periódico ligado aos Diários Associados de Assis Chateaubriand, dedicar-se-á a defender o governo de Luiz Cavalcante.

A Gazeta aponta que, em resposta ao manifesto dos trabalhadores do Porto, o chefe do executivo estadual, por seu turno, apontou que em virtude "da impossibilidade de atender tais pretensões, dirigiu-se ao Ministro da Viação e Obras Públicas, solicitando a incorporação do Porto de Maceió ao Departamento Nacional de Portos e Vias Navegantes". 59 Tendo como resposta dos portuários um novo ofício no qual estes últimos salientavam a sua posição, destacando que "o movimento era pacífico e que visa única exclusivamente ao atendimento de suas reivindicações". Ainda segundo o jornal, em solidariedade aos seus companheiros, todos os sindicatos de Orla marítima haviam entrado em greve no dia 7.

No dia seguinte, enquanto conversava com os portuários em greve, Nilson Miranda, que naquele período exercia o mandato de vereador em Maceió, foi preso. Foi abordado por quatro investigadores que o transportaram até a delegacia, para em seguida ser transferido para a penitenciária do estado. ${ }^{60} \mathrm{O}$ fato causou comoção entre a Câmara de Vereadores da capital. Segundo a Gazeta, tão logo tomou conhecimento do ocorrido, o presidente da Câmara Municipal, Hamilton Morais, dirigiu-se até a Secretaria do Interior, a fim de obter informações acerca dos motivos pelos quais Miranda havia sido detido sem, no entanto, obter alguma resposta satisfatória.

O Sindicato dos Radialistas de Alagoas também distribuiu nota à imprensa, protestando contra a prisão de seu presidente. Na nota, afirmava que a prisão do radialista, de maneira injustificável, assim como já havia acontecido com outros líderes sindicais, já havia se tornado rotineira, desde que Alagoas começou a ser governada por Luiz Cavalcante. A seção alagoana do CGT, além da manifestação de solidariedade com as greves dos portuários, estivadores, conferentes, marítimos e rodoviários autônomos, por meio de nota à imprensa, protestou contra as atitudes violenta e arbitrária da força policial de Luiz Cavalcante. A nota também ameaçava que o CGT deflagraria uma greve geral no estado, caso permanecesse o clima de repressão.

A Câmara Municipal deliberou um estado de "sessão permanente", em obediência a um requerimento do vereador Claudenor Sampaio. Hamilton Morais, outro

57 DELGADO, op. cit., p. 39-40.

58 "Greve na orla marítima: o governo não atende portuários". In: Gazeta de Alagoas. 07 jun. 1963, p. 1.

59 Gazeta. Loc. cit.

60 "CGT ameaça deflagrar greve geral no estado". In: Gazeta de Alagoas. 08 jun. 1963, p. 1. 
vereador, salientou que o legislativo municipal tomaria todas as providências que o caso exigia, já havendo enviado telegramas ao Presidente da República, ao ministro da justiça e ao ministro do trabalho. ${ }^{61} \mathrm{O}$ vereador Roberto Farias, em entrevista à Gazeta, esclareceu como ocorreu a prisão. Na manhã do dia anterior, estava dirigindo-se com o vereador Nilson Miranda, a convite deste, para visitar os diversos sindicatos de trabalhadores. Farias explicou

[...] que foram averiguar se as greves deflagradas à zero hora do dia 07 estavam realmente sendo de caráter pacífico. Quando se dirigiam de um sindicato a outro surgiram 4 policiais que convidaram o vereador em questão para comparecer, a convite até a $2^{\circ}$ Delegacia. Na qualidade de advogado ele, Roberto Farias, protestou contra o ato injusto e, sobretudo inconstitucional do Delegado e que aquilo era uma verdadeira "coação", indo de encontro às leis do País. Em virtude do seu protesto houve, do mesmo modo, pretensões para que também fosse preso. ${ }^{62}$

Não encontramos nenhuma matéria no Jornal de Alagoas que fizesse qualquer menção ao ocorrido com Miranda; além disso, não há notícia na Gazeta sobre quanto tempo ele permaneceu preso. Na matéria "Paralisação dos Portos dá prejuízos incalculáveis"63, a Gazeta informa que se havia estabelecido um contato entre um representante do estado e os grevistas, sem que nenhum entendimento pudesse por fim à greve. A partir de então, não encontramos nenhuma notícia sobre as negociações, bem como sobre o término da paralisação. No entanto, quase dois meses depois, a Gazeta de Alagoas voltaria a estampar, na sua primeira página, a ameaça de uma greve por parte dos funcionários do Porto.

No dia 2 de agosto, a Gazeta informava que os portuários entrariam em greve, a partir do dia seguinte, caso o governador do estado não tomasse as providências para federalização do Porto. ${ }^{64} \mathrm{~A}$ greve, deflagrada em 7 de agosto, estendeu-se ao longo de onze dias, apesar da mobilização das forças policiais para conter o movimento. ${ }^{65}$ Terminou com os portuários tendo a sua reivindicação, a federalização do Porto de Maceió, atendida. ${ }^{66}$

O Jornal de Alagoas deu ampla cobertura aos acontecimentos relacionados a esta greve, principalmente no tocante à atuação do governador de Alagoas nas negociações para a federalização do Porto. Na matéria intitulada "Interessado em resolver o problema do terminal da Petrobras: governador LC"67, o jornal dava notícias procedentes do escritório de Alagoas, no Rio de Janeiro, sobre a movimentação do governador LC naquele estado:

[...] durante o dia de anteontem, visando outros benefícios para o estado de Alagoas, relacionados com a construção do terminal marítimo da Petrobras em nosso estado, a intensificação de pesquisas e exploração do petróleo alagoano, pagamento de Royalties ao nosso estado, urgência na conclusão da linha de transmissão Delmiro - Olho D’Água das Flores e obtenção de recursos Piaçabuçu - Penedo - Junqueiro. ${ }^{68}$

61 "Sessão permanente até que o vereador seja libertado". In: Gazeta de Alagoas. 08 jun. 1963, p. 1.

62 Ibidem.

63 Gazeta de Alagoas. 09 jun. 1963, p. 1.

64 “Greve dos portuários". In: 02 ago. 1963, p. 1.

65 "Prossegue a Greve dos Portuários Apesar das Violências Policiais". In: A Voz do Povo. Maceió, Ano XVII. 18 ago. 1963, n. 30, p.1.

66 Em outra matéria na mesma edição, o jornal relata que ao sétimo dia de greve os portuários conseguiram a decretação da federalização do porto, só que, segundo Miranda, o dinheiro liberado teria sido retido pelo governador e esta greve já estaria no décimo primeiro dia.

67 Jornal de Alagoas. 11 ago. 1963, p. 5.

68 Ibidem. 
A intenção do jornal, ao veicular notícias como essa, é a de construir uma imagem de Luiz Cavalcante como um governante sensível às demandas dos trabalhadores, ao mesmo tempo em que enaltece a sua participação nas negociações que visavam implementar avanços econômicos com a exploração do petróleo em terras alagoanas. Contudo, em momento algum o jornal faz alguma menção sobre a resistência dos trabalhadores e sobre a repressão policial que eles estavam enfrentando.

No dia 18 de agosto, no editorial "O salário dos servidores do Porto"69, ao fazer uma análise sobre a greve, o jornal afirma que "os servidores do Porto de Maceió, cansados de esperar por uma melhoria salarial que a administração estadual não lhes pode dar, foram à greve e conseguiram em tempo recorde que saísse o decreto de federalização do nosso porto". Neste trecho se pode observar mais uma defesa de Luiz Cavalcante, já que pressupõe que o governador teria atendido às reivindicações salariais dos trabalhadores caso dispusesse de recursos para isso.

Mas o tom do editorial na verdade tem outro alvo, o presidente João Goulart:

Há cerca de dois anos passados, o presidente da República montou no Brasil um dispositivo sindical para servir aos seus desígnios políticos. Esperava-se que o congresso cedesse na aprovação de uma lei ou de um novo gabinete apertava o botão do dispositivo e os trabalhadores entravam em greve. O congresso não resistia à pressão. De tanto usar o dispositivo, um dia esse se voltou contra ele. Os trabalhadores verificaram que precisavam também defender suas reivindicações e o expediente que o governo lhes entregara era ideal: fazer greve. ${ }^{70}$

Nesse trecho do editorial, o jornal intenta construir a imagem de que Jango manipularia os trabalhadores para que pudesse obter vantagens políticas com isso. Antes e depois do golpe de 1964, não foram poucas as iniciativas que provocaram e induziram à desqualificação do presidente João Goulart e de sua trajetória política. Foram desenvolvidas, com eficácia crescente, por seus opositores desde sua posse como ministro do trabalho em 1953. Estenderam-se, com vigor, à conjuntura pré-1964 e ganharam fôlego nos anos sequentes ao golpe que o depôs. A elas se somou um silêncio que urdiu um esquecimento consoante com o objetivo dos responsáveis pelo regime autoritário de legitimar suas ações. ${ }^{71}$

O Jornal de Alagoas, com editoriais deste tipo, começava a ensaiar uma campanha que algum tempo depois se tornaria vigorosa em sua linha editorial. Entre o final de 1963 e o início de 1964, os ataques dirigidos ao presidente vão aumentar consideravelmente e, assim como outros jornais do resto do país, vão contribuir para que a crise política do governo Goulart atinja sua tensão máxima.

Em setembro de 1963, a greve deflagrada pelos bancários durou onze dias, paralisando uma grande parte dos estabelecimentos bancários de Maceió. No dia 2, em uma reunião realizada no Palácio do Trabalhador, os bancários deliberaram a aprovação de um "estado de greve", podendo, a qualquer momento, deflagrarem

69 Jornal de Alagoas. 18 ago. 1963, p. 4.

70 Ibidem.

71 GOMES, Angela de Castro. Memórias em disputa: Jango Ministro do Trabalho ou dos trabalhadores? In: Marieta de Moraes Ferreira (Org.). João Goulart: entre a memória e a história. Rio de Janeiro: Editora FGV, 2006. Neste capítulo, Gomes aponta que tal fato decorreu da habilidade de João Goulart nas relações desenvolvidas com o movimento sindical e demais organizações populares. Desde seu mandato como ministro do trabalho e com maior ênfase quando presidente da República, buscou, nas demandas dos trabalhadores referências para suas políticas governamentais. Enfrentou, em razão dessa opção, forte oposição conservadora. Os mesmos setores que se opuseram à sua posse, em 1961, articularam-se para depô-lo, em 1964. 
o movimento paredista. ${ }^{72}$ Segundo nota publicada na Gazeta de Alagoas, a reunião foi convocada

para apreciar a posição dos banqueiros face às reivindicações dos empregados, que pleiteiam melhoria salarial. Após muitos debates, os bancários decidiram publicar nota oficial, onde definem a posição assumida, bem como os motivos que determinaram aquela atitude. ${ }^{73}$

Assim como aconteceu com a greve dos portuários, percebemos que a Gazeta de Alagoas se esforçou em fazer uma cobertura diferente da feita pelo Jornal de Alagoas no tocante aos acontecimentos relativos à greve. Talvez o ponto mais significativo seja o espaço para a publicação das notas dos sindicatos de trabalhadores, algo que não aconteceu com o Jornal de Alagoas, que direcionou as suas matérias e editoriais a atacar todo e qualquer movimento dos trabalhadores que apontasse em direção à ruptura com a ordem.

A greve foi deflagrada no dia 11, depois de uma série de reuniões entre banqueiros e bancários, os quais não chegaram a nenhum acordo que viesse solucionar o problema do aumento salarial. ${ }^{74}$ Segundo a Gazeta de Alagoas, os patrões haviam

oferecido o aumento baseado no aumento do custo de vida no estado, o que não foi aceito pelos bancários por ser, segundo eles, uma forma de atrasar o reajuste salarial, que não virá de maneira justa, por falhar na maioria das vezes a estatística oficial. Afirmaram ainda que nenhum levantamento foi feito e que a fórmula apresentada pelos empregadores é apenas uma maneira de levar a classe ao desespero. ${ }^{75}$

Os bancários decidiram, então, deflagrar a greve da categoria diante da falta de um acordo com os patrões. Segundo a Gazeta, "organizados os piquetes de greve, todos os presentes sairiam às ruas em passeata pacífica e ordeira. Na redação deste jornal, explicaram as razões de sua greve. Paralisadas, portanto as operações de crédito de nossa capital, até que se encontre uma solução para o problema".

No dia 20 de setembro, após uma série de negociações entre os bancários e os banqueiros, intermediada pelo juiz do trabalho Paulo Quintela, os trabalhadores aceitaram a solução proposta pelo juiz. ${ }^{76}$ Já no dia anterior, "a solução proposta pelo juiz trabalhista havia sido aceita pelo sindicato dos empregados em estabelecimentos bancários de Maceió, os quais apenas pleitearam a extensão os seus feitos aos bancários do interior do estado". Todavia, os banqueiros se mantiveram "impassíveis na sua oferta de setenta por cento sobre os salários resultantes do mesmo acordo. Alegaram total incapacidade de meios financeiros dos bancos para atenderem a proposta".

Com o fim da greve em 21 de setembro, o editorial "Volta a normalidade a situação bancária"77, o Jornal de Alagoas fazia questão de elogiar o Tribunal do Trabalho pelo empenho nas negociações para que a greve chegasse ao fim e aos trabalhadores da Caixa Econômica Federal por não terem aderido à greve, permitindo que as transações bancárias na capital não fossem interrompidas totalmente.

72 "Bancários em estado de greve ameaçam paralisar atividades". In: Gazeta de Alagoas. 03 set. 1963, p. 1

73 "Sindicato dos empregados em estabelecimentos bancários de Maceió: nota oficial". In: Gazeta de Alagoas. 10 set. 1963 , p. 1.

74 "Greve dos bancários começa hoje". In: Gazeta de Alagoas. 11 set. 1963, p. 6.

75 Ibidem.

76 "Grevistas e banqueiros de Alagoas ainda não chegaram a entendimento". In: Jornal de Alagoas. 20 set. 1963, p. 5.

77 Jornal de Alagoas. 21 set. 1963, p. 4. 
O ano de 1963 continuaria a assistir a uma atividade cada vez maior do movimento sindical, bem como do número de greves. Quase diariamente, os jornais alagoanos traziam notícias sobre as greves que estouravam por todo o país, alarmando a população alagoana do caos para o qual o Brasil estava - a passos largos — caminhando. Em novembro de 1963, na cidade de São Paulo, aconteceu uma greve que, segundo Negro e Silva, vislumbrou a representação de setecentos mil trabalhadores lotados nas bases de setenta e nove sindicatos e quatro federações. ${ }^{78}$

Segundo os autores, a Greve dos 700 mil destaca-se devido à tentativa dos trabalhadores em estabelecer uma nova forma de negociação salarial coletiva que abrangesse todas as categorias sindicais, por meio da representação direta dos líderes representantes das principais organizações horizontais do país. A análise desse movimento retrata a luta dos trabalhadores para legalizar a CNTI (Confederação Nacional dos Trabalhadores da Indústria) e o PAC (Pacto de Ação Conjunta), bem como as diferentes interpretações apresentadas pelos magistrados do Tribunal Regional do Trabalho (TRT) e pelo Tribunal Superior do Trabalho (TST). ${ }^{79}$

Os autores concluem, destacando o fato de se tratar de uma greve eclodida em um momento político extremamente tenso. A campanha liderada pela oposição ao governo Goulart disseminava o medo de que uma "república sindicalista" se instalasse no país. Desde meados de 1962, o CGT e o PAC atuavam como entidades centralizadoras dos sindicatos, tendo conquistado algumas vitórias, entre elas o salário-família, a realização do plebiscito, o abono de Natal e a não decretação do estado de sítio. Nesse contexto, a Greve dos 700 mil representou um momento importante para a história do movimento da classe trabalhadora, devido ao avanço das reivindicações e negociações travadas durante o movimento paredista, que visava a amplas mudanças nas relações entre patrões e empregados. ${ }^{80}$

\section{Rumo ao desfecho}

O ano de 1964 foi decisivo nas disputas entre os grupos dominantes e os segmentos que se manifestavam a favor das Reformas de Base; entre elas a reforma agrária, cujo significado representou um impasse nas disputas sociais em Alagoas. As elites dominantes que tinham no latifúndio a base estratégica do seu poder de dominação temiam uma radical distribuição de poder caso se realizasse esse programa de reformas.

As constantes greves colocaram em alerta os grupos dominantes, uma vez que as mobilizações de trabalhadores no campo adquiriam cada vez mais representação. Em janeiro, duas greves ajudaram a acirrar os ânimos entre o governo do estado e os movimentos sociais em Alagoas: a greve dos trabalhadores em combustíveis e a greve dos trabalhadores rurais.

No dia 9 de janeiro, o Jornal de Alagoas trazia, numa matéria, a entrevista com o presidente do Sindicato dos Trabalhadores na Indústria de Combustíveis e Mineração, Etevaldo Dantas, sobre o movimento paredista que havia sido iniciado no dia anterior. ${ }^{81}$ Dantas declarou ao jornal que a categoria tentou negociar durante todo o mês de dezembro de 1963 e que as principais reivindicações giravam em

78 NEGRO e SILVA. op. cit., p. 82.

79 Ibidem, p. 84.

80 Ibidem, p. 85.

81 “Começa a faltar gasolina". In: Jornal de Alagoas. 09 jan. 1964, p. 6. 
torno de garantias trabalhistas (nível de salário mínimo, décimo terceiro etc.) já regulamentadas pelo governo federal em outros estados da Federação.

Nos nove dias que a greve durou, as matérias do Jornal de Alagoas deixavam clara a preocupação de que o estado mergulharia numa grande crise, caso o abastecimento de combustível continuasse parado. No dia seguinte, uma reunião entre os representantes dos trabalhadores e o secretário do Interior, Nilo Floriano Peixoto, não trouxe um entendimento sobre o fim do movimento. ${ }^{82}$

Em poucos dias, o movimento passou a contar com o apoio do CGT e de alguns sindicatos, como por exemplo o dos Trabalhadores do Petróleo e o dos Jornalistas ${ }^{83}$ - que tinham Alan Rodrigues Brandão e Nilson Miranda respectivamente como presidentes - e que se mantinha "irredutível" na manutenção da greve. ${ }^{84}$ Aqui se nota a clara posição conservadora do jornal, ao querer retratar os trabalhadores como não sensíveis em aceitar um acordo para pôr fim à paralisação. Outra assembleia no dia 11, presidida pelo representante do CGT e presidente do sindicato dos bancários, Roland Benamour, decidiu novamente pela rejeição à proposta dos patrões. ${ }^{85}$

No dia 12, o jornal relatava que a greve continuava sem um entendimento final, e que o movimento paredista dos trabalhadores nas empresas comerciais de minérios e combustíveis de Alagoas já trazia "enormes prejuízos" para a sociedade alagoana. ${ }^{86}$ No título da matéria "Greve dos trabalhadores em combustíveis pretende paralisar o Estado: Gasolina nem pra coletivo", é notável a tentativa de se construir uma imagem de que, os prejuízos da paralisação não apenas afetavam os possuidores de automóveis, mas também a grande maioria da população que dependia de transporte público para se locomover até os seus locais de trabalho.

Em outra matéria, o jornal relata que na tarde do dia anterior esteve reunido com o CGT, discutindo uma série de problemas da organização, mas nenhum dizia respeito à greve ou a sua duração. Dois dias depois, o jornal alerta para a "fase de afirmação" que o movimento havia alcançado e para a "falta de pulso firme" das autoridades com os grevistas. ${ }^{87}$

Nesse aspecto, é difícil entendermos o que seria essa "falta de pulso", já que o Jornal de Alagoas não faz críticas à administração do governador Luiz Cavalcante, nem ao secretário do Interior, João Mendes Mendonça, este último responsável pela segurança pública em Alagoas.

Prova disso é que, quando o governador mobilizou a Secretaria do Interior por meio do Cel. João Mendes Mendonça para abastecer os postos de gasolina da capital, o Jornal de Alagoas se apressou em elogiar a posição "nacionalista" e "democrática" do governador, ao garantir o abastecimento de combustível antes que o estado entrasse em colapso pela sua falta. ${ }^{88}$ As posições nacionalista e democrática do governador se expressam de forma que, no clima de radicalização política da época, as greves daquele tipo seriam fomentadas pelos agentes do comunismo

82 "Greve dos trabalhadores em combustíveis pretende paralisar o Estado: Gasolina nem pra coletivo". In Jornal de Alagoas. 10 jan. 1964.

83 “Sindipetro e Sjpea”. In: Jornal de Alagoas. 11 jan. 1964, p. 6.

84 "Diversas tentativas de acordo foram repelidas: os grevistas dos combustíveis irredutíveis". In: Jornal de Alagoas, p. 5.

85 "Greve continua: gasolina cada vez mais cara". Idem, p. 5.

86 “Greve continua: gasolina é cada vez mais escassa”. In: Jornal de Alagoas. 12 jan. 1964, p. 6.

87 “Estado as vésperas da paralisação total: falta gasolina por falta de pulso firme". In: Jornal de Alagoas. 14 jan. 1964, p. 6.

88 "Governo interveio e garantiu o abastecimento em todo o Estado pelo preço real". In: Jornal de Alagoas. 16 jan. 1964, p. 6. 
ateu e internacional, que por intermédio da subversão e da agitação visavam instaurar no país o caos e a desordem.

Para a decepção do jornal, no fim da mesma matéria, foi noticiado que a greve permaneceria. Dois dias depois, um acordo entre trabalhadores e patrões pôs fim à greve que, segundo uma matéria do jornal do PCB, A Voz do Povo, foi vitoriosa para os trabalhadores. ${ }^{89} \mathrm{O}$ jornal relatou que a aliança com o CGT e o apoio de outros sindicatos foram alguns dos elementos decisivos para o sucesso do movimento, e que a vitória na greve serviu como fator de fortalecimento do movimento operário frente aos interesses imperialistas dos exploradores do petróleo, tanto em Alagoas como no Brasil.

Por seu turno, o governador Luiz Cavalcante fez publicar no Diário Oficial de Alagoas duas matérias em que a sua posição no desfecho do movimento grevista foi bastante elogiada. Na primeira, governador e secretário do Interior eram enaltecidos

pela sua [ilegível] e patriótica atuação na recente crise provocada pela falta de combustíveis em nosso Estado, o cel. João Mendes de Mendonça continua recebendo manifestações de apreço de todas as classes realmente cônscias de suas responsabilidades..$^{\circ}$

Na segunda, trazia na íntegra uma mensagem da Associação Comercial de Palmeira dos Índios, que dizia:

Assinado pelo Sr. Jorge Morais, presidente da Associação Comercial de Palmeira dos Índios, recebeu o governador Luiz Cavalcante, em data de ontem, o seguinte telegrama: "A Associação Comercial de Palmeira, reunida em assembleia extraordinária, aprovou votos de aplausos e apoio às medidas tomadas por V. Excelência, no sentido de evitar o prolongamento grevista dos distribuidores dos derivados de petróleo, que ameaçaram transformar a vida econômica do Estado". ${ }^{91}$

Essa greve também foi representativa por outro aspecto, já que, além do abastecimento de combustível, como já mencionamos acima, havia outro ponto importante embutido no problema. Rodrigo Motta, no que chama de Segundo grande surto anticomunista ${ }^{92}$, que ocorreu entre os anos de 1961 e 1964, discute que as ondas grevistas crescentes a partir de 1963 foram um dos argumentos usados pelos golpistas para deflagrarem o movimento civil-militar em março de 1964.

Motta aponta para o alerta que se fazia à "presença comunista em diversos setores da vida nacional, nas organizações sociais e principalmente no aparato estatal". ${ }^{93}$ Denunciava-se que os comunistas estariam presentes em vários órgãos da administração como o Ministério do Trabalho, nas instituições previdenciárias e, acima de tudo, nas Forças Armadas. ${ }^{94}$ Mas era no tocante à Petrobras e aos combustíveis que a situação era mais delicada:

89 "Vitoriosa greve dos trabalhadores em combustíveis". In: A Voz do Povo. Maceió, Ano XVII. 18 jan. 1964, n.2, p.1.

90 “As classes produtoras aplaudem e apoiam atitude do secretário”. In: Diário Oficial. 17 jan. 1964, p. 1.

91 “Associação Comercial de Palmeira: Aplausos e apoio ao governador”. In: Diário Oficial. 24 jan. 1964, p. 1.

92 MOTTA, Rodrigo Patto Sá. Em guarda contra o perigo vermelho: o anticomunismo no Brasil 1917-1964. São Paulo: Perspectiva, 2002, p. 231.

93 Ibidem, p. 255.

94 Ibidem, p. 256. 
No caso da estatal petrolífera, a alegada influência comunista gerou polêmicas acirradas ("A sovietização do Petróleo"95) provocou a constituição de uma CPI no Congresso. A ansiedade causada pela presença esquerdista na Petrobras devia-se à importância estratégica do controle sobre os combustíveis, no caso de uma eventual conflagração militar. ${ }^{96}$

Enquanto a greve dos combustíveis mal chegava ao fim, na edição de 18 de janeiro de 1964, o jornal A Voz do Povo estampava na sua primeira página a matéria “50 mil camponeses irão à greve pelo $13^{\circ}$ mês de salário!”. A matéria tratava da mobilização na qual estavam envolvidos o CGT e a Federação de Trabalhadores Rurais, que exigia o pagamento do décimo terceiro mês de salário aos trabalhadores, pois nenhuma usina havia feito até aquele momento. ${ }^{97}$

Caso não houvesse o pagamento, cinquenta mil camponeses paralisariam suas atividades em todo o estado e que a "atual situação se devia a inércia da delegacia do trabalho". O jornal cita ainda que "o governador Luiz Cavalcante seria o responsável pela vida dos camponeses uma vez que os trabalhadores sofreriam a represália violenta dos usineiros".

No mesmo dia, o Jornal de Alagoas trazia uma matéria que revelava toda a sua preocupação caso essa greve, a primeira de trabalhadores rurais no estado, fosse iniciada. ${ }^{98}$ Uma entrevista com o presidente da FTRAL, Manuel Salustiano Lopes, confirmava que de fato nenhum patrão havia pagado o $13 .^{\circ}$ salário.

É importante analisar com mais cuidado o que esse fato representou na época, uma vez que o estado estaria presenciando pela primeira vez uma greve de trabalhadores do campo, estes últimos marcados pela relação de dominação que mantinham com sua classe patronal. Se, na cidade, os trabalhadores, desde meados da década de 1950, vinham num crescendo em relação a sua capacidade de mobilização e enfrentamento perante a classe patronal, no campo a situação era um pouco mais delicada.

Em várias matérias do jornal A Voz do Povo, encontramos denúncias de violências sofridas por trabalhadores, de espancamentos e de expulsão dos engenhos pelos proprietários, alguns exercendo mandatos no cenário político da época. ${ }^{99}$ Assim, o Jornal de Alagoas usava de uma greve deflagrada por trabalhadores do campo para fazer crer que o país se encontrava num caminho sem volta rumo ao caos e à desordem.

No dia 22 de janeiro, uma reunião na Associação dos Plantadores de Cana de Alagoas - ASPLANA reuniu os representantes dos trabalhadores e dos patrões para a discussão do pagamento do $13 .^{\circ}$ salário. Nessa reunião, esteve presente o então Delegado Regional do Trabalho, Sr. Hilton Loureiro, que segundo o Jornal de Alagoas visava encontrar uma solução satisfatória para evitar que a greve fosse levada a termo. ${ }^{100}$ Apesar de todas as tentativas no sentido de impedir a sua deflagração, no dia 29, o jornal trazia a matéria "Camponeses de três fazendas da Usina Leão e de uma da Usina Santa Clotilde em greve pelo $13^{\circ}$ Salário"101, noticiando que

95 Titulo de Editorial. O Globo. 08 nov. 1963, p. 1 apud. MOTTA, p. 256.

96 Ibidem, p. 257.

97 “50 mil camponeses de Alagoas irão à greve pelo $13^{\circ}$ mês de salário". In: A Voz do Povo. 18 jan. 1964, p. 1.

98 "Camponeses de Alagoas ameaçam com greve se não for pago o Décimo Terceiro salário até o dia 27". In: Jornal de Alagoas. 18 jan. 1964, p.6.

99 Como é o caso do deputado estadual Antonio Gomes de Barros da cidade de União dos Palmares, denunciado na matéria "Protestos de massas contra o espancamento do líder camponês José Pedro de Lima". In: Voz do Povo. Ano XVII. 04 ago. 1963, n. 26, p. 2.

100 "Camponeses vão receber décimo terceiro mês". In: Jornal de Alagoas. 23 jan. 1964, p. 6.

101 "Camponeses de três fazendas da Usina Leão e de uma da Usina Santa Clotilde em greve pelo $13^{\circ}$ Salário". In: Jornal de Alagoas. 29 jan. 1964, p. 6. 
trabalhadores haviam entrado em greve a despeito da decisão de que ela não deveria se iniciar no dia 27. Neste mesmo dia houve uma reunião entre os trabalhadores e representantes patronais e do Ministério do Trabalho, porém não se avançou na discussão sobre o pagamento do $13 .^{\circ}$.

No dia seguinte, o Jornal de Alagoas trazia notícias sobre a greve em quatro fazendas e destacava, ainda, que

emissários dos camponeses que entraram em greve segunda-feira última em quatro fazendas de canavieiras do nosso estado, voltaram desta capital com instruções da sua Federação para retomarem ao trabalho imediatamente, uma vez que os sindicatos rurais decidiram suspender a parada marcada para o dia 27 em todo o Estado. [Ilegível o resto]. ${ }^{102}$

Depois da matéria "Camponeses receberão décimo terceiro de salário: usineiros concordam" ${ }^{103}$, não há mais informações no Jornal de Alagoas sobre o andamento, nem da greve (que de fato aconteceu) nem dos entendimentos tomados para a sua realização. No dia 9 de fevereiro, o jornal A Voz do Povo estampava em sua primeira página que " 5000 Camponeses paralisam o trabalho nas fazendas e usinas pelo cumprimento das leis"104, destacando como principal reivindicação o pagamento do 13. ${ }^{\circ}$ salário e do salário mínimo. Outra importante informação trazida pelo jornal é a denúncia da reação armada dos latifundiários reforçada pelo aparato policial do estado ${ }^{105}$ e conclamava que os outros grupos urbanos (operários e estudantes) decretassem greve geral como forma de solidariedade aos camponeses.

Diante desse quadro é um pouco difícil termos uma visão global desses dois movimentos, já que a Gazeta Alagoas não deu atenção a eles e também só dispomos de duas edições do jornal A Voz do Povo (a de 18 de janeiro e a de 09 de fevereiro de 1964) que fazem menção a esses dois eventos. Como mencionamos acima, depois do dia 30 de janeiro, o Jornal de Alagoas se cala sobre o assunto. Outro fator importante desse "silêncio" também pode ser verificado no Diário Oficial, no qual não há notícias sobre o desenrolar dos fatos no caso da greve dos trabaIhadores rurais, já que a repercussão da atuação do governador e do secretário do Interior na greve dos combustíveis foi explorada tanto no Diário Oficial como no Jornal de Alagoas.

\section{Palavras Finais}

Quando o major Luiz Cavalcante assume o governo do estado em 1961, os movimentos sociais que alcançaram significativa expressão durante o governo de Sebastião Marinho Muniz Falcão no período anterior (1956-1961) viram essa conjuntura mudar radicalmente com a sua eleição. Declarado anticomunista, Cavalcante estava ligado ao complexo IPES/IBAD e colocava-se numa situação de oposição ao governo Goulart e ao seu projeto "nacional reformista", tendo atuado nas negociações que introduziram a experiência parlamentarista após a renúncia de Jânio Quadros em 1961 e sendo um dos principais articuladores, no Nordeste, do golpe militar que depôs o presidente da República.

102 "Mais esclarecimentos sobre a greve em quatro fazendas". In: Jornal de Alagoas. 30 jan. 1964, p. 6. 103 Jornal de Alagoas. 06 fev. 1964, p. 6.

104 A Voz do Povo. 09 fev. 1964, p. 1.

105 Ibidem, p. 4. 
Na disputa eleitoral de 1960 a oligarquia canavieira procurou reeditar a tradição política alagoana de ter um governador comprometido com os grupos mais conservadores, apoiando a candidatura do Major Luiz Cavalcante para o governo do Estado. Isso seria um reflexo de que as propostas nacional-desenvolvimentistas que o governo Muniz Falcão procurou implementar em Alagoas representaram um obstáculo às elites e seu projeto de dominação dos trabalhadores. Somado a isso, a crescente mobilização dos grupos de esquerda ao longo de toda a década de 1950 e início da de 60, e a atuação cada vez maior desses grupos no cenário político causaram preocupações nas hostes elitistas, dado que o avanço dessas esquerdas era interpretado como uma guinada da sociedade rumo ao comunismo.

A sequência dos fatos demonstrou que a atuação de Luiz Cavalcante para conter a crescente - e intensa - mobilização dos grupos esquerdistas pautou-se pelo uso da força policial do estado para reprimir as atividades daqueles que representavam naquele momento a subversão da ordem estabelecida. Em 1964, antes do golpe civil-militar, Luiz Cavalcante chegou a impedir a entrada de Miguel Arraes, então governador de Pernambuco, e de Seixas Dória, governador de Sergipe (ambos identificados com as propostas reformistas do presidente João Goulart), para participar de um comício em Maceió, utilizando-se de todo o aparato militar estadual para efetuar essa proibição. ${ }^{106}$ 